\title{
Facing the Devil's Test: The Truth According to René Girard ${ }^{1}$
}

\author{
René Girard, Laurent Linneuil, Abbé de Tanoüarn
}

Certitudes: René Girard, you entitled your book Les Origines de la Culture ${ }^{2}$ [Evolution and Conversion ${ }^{3}$. Was it your wish to reorient criticism towards an unrecognized aspect of your work, namely, the foundational character of violence?

René Girard: Yes, the foundational character of violence is little understood, little perceived. In English, we speak of a programmatic title, that is, a title designed to be useful to a general audience. I used rather "sensationalistic" titles in the past, but this no longer works...

Certitudes: And so, for this book you choose a less scandalous, more classical title, one that symbolizes your whole research. Isn't it also a way of responding to accusations levelled against the exaggerated pessimism of your thought?

René Girard: The programmatic title is somehow more explanatory than the others. As for the fact that the title symbolizes my entire work, this was already said of my previous book, I See Satan Fall Like Lightning... But "I See Satan Fall Like Lightning" is an ambiguous phrase because where does he fall? To earth... And the moment he falls to earth is precisely the moment at which he causes the most harm. He becomes free to do what he wants; it is therefore a phrase that is often interpreted in an apocalyptic sense. Of course, it is the announcement of Satan's end but not of his immediate end, to the extent that he is released. We have the symbolism of ligature, so to speak, and of Satan's release.

Certitudes: Then Satan is released in the bonds of culture...?

René Girard: Indeed. Does it mean that Satan is no longer retained? Remember the text stating that "It is through Beelzebul [the prince of devils] that he drives devils out." And

\footnotetext{
${ }^{1}$ René Girard, «René Girard : sa vérité à l'épreuve du diable », Nouvelle Revue Certitudes, 16 (2005). The original French version of this interview conducted by Laurent Linneuil and the Abbé de Tanoüarn can be accessed via the following link: http://certitudes.free.fr/nrc16/nrc16i.htm (accessed October 21, 2017).

2 René Girard, Les Origines de la Culture (Paris : Desclée de Brouwer, 2004)

${ }^{3}$ René Girard, Evolution and Conversion: Dialogues on the Origin of Culture (New York: Continuum International Publishing, 2008).

This is an Open Access article distributed in accordance with the Creative Commons Attribution Non Commercial (CC-BY-NC-ND 4.0) license, which permits others to copy or share the article, provided original work is properly cited and that this is not done for commercial purposes. Users may not remix, transform, or build upon the material and may not distribute the modified material (bttp:/ / creativecommons.org/licenses/by-nc/4.0/)
} 
Jesus replies, "Now if it is through Beelzebul that I drive devils out [through whom do your own sons drive them out? They shall be your judges, then. But if it is through the finger of God that I drive devils out, then the kingdom of God has indeed caught you unawares]." [Luke 11: 19-20 NJB]. The idea of driving out devils "through Beelzebul" is very deep: many of Jesus's interlocutors claim the expulsion of the demon is made through Satan. The point here is the expulsion of culture. But in the Judaism of the time, sacrifices were made. How did it interpret those sacrifices? I am sure there were prophets who were very suspicious of those sacrifices, who asked that they cease, who said that God opposes them. And I do think this aspect has been minimized.

Certitudes: And this is the reason why you state in When These Things Begin that Satan is order...

René Girard: Satan is, to a certain extent, the cultural order in its violent dimension. But one must beware: this doesn't mean that we can condemn the order since, in any event, the sacrificial movement always tends towards less violence. If it is true, as I say, that violence is somehow fatal to humanity which cannot organize itself without sacrifice, then it is evident that sacrifices are necessary and accepted by God. One can refer to words in the Gospel such as: "Moses [because of the hardness of your hearts] suffered you to put away your wives [but from the beginning it was not so]." [Matthew 19:8 KJV]. God made concessions in classic Judaism which are no longer present in Christianity to the extent that the sacrificial principle has been revealed.

Certitudes: From the moment the founding murder leads to sacrifice and we recede from the original murder, sacrifice tends to transform itself into a ritual, a less and less violent institution?

René Girard: The sacrifice gets institutionalized by changing the victim - I admire what Kierkegaard says on Abraham's sacrifice. The primary meaning is therefore historic: it is the move from human to animal sacrifice that represents an immense progress, one that only Judaism interprets, in the sacrifice of Isaac. Judaism is the only religion that symbolizes this progress in a great sequence, one of the first sequences of the Old Testament. One must not forget what this text accounts for and what tradition has not sufficiently taken into account: the Old Testament in its entirety is situated within the context of the sacrifice of the first born. It is absurd to connect Christianity to the sacrifice of the first born, but behind Judaism we find what is in every middle-oriental civilization, especially in that of the Phoenicians: the sacrifice of children. When Flaubert depicts it in Salammbô, Sainte-Beuve is quite wrong to mock him because what Flaubert is talking about is very real. Researchers discovered in the cemeteries of Carthage tombs that contained a mixture of half-burnt animals and children who were half-burnt at their death. Flaubert was much criticized for the scene of the god Moloch in which Carthaginian parents throw their children into the furnace. Yet, recent research proves Flaubert was right, contra Sainte-Beuve. Ultimately, it is the novelist who is right: this scene is one of the most terrifying and magnificent in Salammbô. The intellectual fashion of recent years according to which violence was invented 
by the Western world during the era of colonialism is a complete absurdity and archeologists have rightly ignored it. In the United States, research programs are being set up, notably on the Mayas. The latter have often been considered "anti-Aztecs": they would not have practiced human sacrifice. But, then, as soon as the littlest archeological excavation is made, we discover extraordinary things: among the Mayas, there are square kilometers of buried cities. It is a wonderful population with numerous temples and traces of human sacrifice are everywhere: the skulls of new-born children mixed with animal skulls.

Certitudes: Your rereading of the Bible places violence at the heart of human relations, quite surprisingly, as though you felt tempted to move the original sin from Adam and Eve to Cain and Abel...

René Girard: That is a very good observation. Scenes of Adam and Eve refer precisely to mimetic desire: Eve receives desire from the serpent and Adam receives it from Eve and then when God later asks the question, the same series is remade backwards. Adam says, "It is her [fault]" and Eve says, "It is the serpent's." For that matter, the serpent bears primary responsibility, since God punishes it more than anyone else. But the first consequence of all this is Cain and Abel. And the fact that the former is the cause of the latter isn't much developed. Adam and Eve are mimetic rivalry-mimetic desire is conveyed from one to another and, thereafter, to the war of enemy brothers and the foundation of the community. What is most striking in the story of Cain and Abel is that the text states the first society was founded by Cain without mentioning how. In fact, the founding act is Abel's murder. Is that clear to the exegetes? I do not think so.

Certitudes: In effect, you show it is murder that founds the prohibition of murder...

René Girard: Of course. There is, by the way, a paper of Giuseppe Fornari which focuses on what we called, in the $19^{\text {th }}$ Century, Cainism. Writers from the esoteric tradition, such as Nerval, were very interested in the subject. In it they perceived a "literary diabolism" that was very fruitful. One never knows what it is precisely because when literary critics mention it, they never go into much detail. There are some of Nerval's texts that make allusions to Cainism, that is, to the esoteric and dark aspects of romanticism in religion. Writers such as Joseph de Maistre were sensitive to it. They later influenced thinkers such as René Guénon. I do not, of course, belong to this movement, but the term "Cainism" interests me because it emphasizes the murderous nature of man. Nerval loved esoterism, but did not push his research very far. In Nerval, Cainism was more poetic than scholarly. But I wonder to what it truly corresponds on the level of ideas: what clear definition of Cainism could we give?

Certitudes: In its reading of Adam and Eve, classical exegesis insists on original sin, and you shift this reading onto the level of mimetic desire...

René Girard: It is easy to find Gospel texts mentioning the fact that Satan is a murderer from the beginning: "You are from your father, the devil [and you prefer to do what your father wants]. He was a murderer from the start [he was never grounded in the truth; there is no truth in him at all]." [John 8: 44 NJB]. In the eighth chapter of the Gospel according 
to Saint John, which portrays the beginning of culture, it therefore says: "You believe yourselves to be the sons of God, but you are very obviously the sons of Satan since you do not even know what this is all about. You believe yourselves to be the sons of God, a natural extension of him, without suspecting that you remain within the domain of sacrifice." But those texts are never truly read. What is Saint John's reproach to the Jews? To what extent does he distinguish himself from orthodox Judaism in this reproach...? There we have real questions...

Certitudes: He reproaches the Jews for showing off their established filiation...

René Girard: Yes, without seeing their own violence, without seeing, in a certain way, the original sin. "We are Abraham's descendants [...They answered and said to Him, "Abraham is our father.]" [John 8:33 NASB]. Jesus replies: "If you are Abraham's children, do the deeds of Abraham." [John 8:39 NASB]. Now, it is truth that makes us free. All this goes to show that while there is no question of defining original sin, it is nevertheless linked to violence and religion as in the archaic religions or as in Christianity which remains distorted by an archaism it never fully overcomes in history. I would be careful not to define original $\sin$.

Certitudes: But what seems very surprising in the Bible is that we do not know why Abel is preferred to Cain...

René Girard: Paradoxically, there might be a reason that appears in Islam. Abel is the one sacrificing animals and we are at the stage when Abel does not want to kill his brother, perhaps because he sacrifices animals, whereas Cain is the agriculturist for whom there are no animal sacrifices. Cain has no other way to cast out violence than to kill his brother. There are quite extraordinary texts in the Quran stating that the animal sent by God to Abraham to save Isaac is the same animal killed by Abel to prevent him from killing his brother. This is fascinating and shows that the Quran is not insignificant on the biblical level. It is very metaphorical but incomparably powerful. I am deeply struck by it. You have very similar scenes in the Odyssey, the extraordinary scenes of the Cyclops. How does one escape from the Cyclops? By hiding oneself behind the animal. And in the same way that Isaac touches the skin of his son—-to identify Jacob who is wearing an animal skin—so the Cyclops touches the animal and sees that the man he is looking for and would like to kill is not there. In the Odyssey, it therefore emerges that the animal saves the man. In a certain way, the Cyclops' herd of sheep is what saves [Ulysses and his friends]. We find the same idea many years later, in One Thousand and One Nights and in the Islamic world, and this part of the story of the Cyclops disappears, it is no longer necessary, it no longer plays a role. But in the Odyssey, there is an absolutely remarkable intuition of sacrifice.

Certitudes: You have said the denunciatory aspect of the founding murder in Jesus's discourse has been rather poorly understood-people often perceive it as anti-Semitic. What purpose is served by the advent of Christianity, if it has been so little understood? Has it not resulted in an explosion of mimetic rivalry? 
René Girard: We could say it resulted in explosions of mimetic rivalry, in clashes between enemy brothers. The main clash between enemy brothers in history is, indeed, the one between Jews and Christians. But early Christianity is dominated by the Epistle to the Romans. It states that the fault of the Jews is very real, but that it is your salvation. Christians, please do not pride yourselves. You have been engrafted thanks to a fault of the Jews. We detect the idea that Christians might themselves prove unworthy of the Christian revelation, as unworthy as the Jews proved of their own. It is my sincere belief that the foundation of contemporary theology must be sought here. Mgr. Jean Marie Lustiger's book The Promise is admirable, in particular what he says about the Massacre of the Innocents and the Shoah. One has to acknowledge that Christianity has nothing of which to boast. Christians inherit from Saint Paul and the Gospels in the same way that the Jews inherited from Genesis, Leviticus, and the whole of the Law. But Christians have not understood this because they kept fighting and despising the Jews.

Certitudes: They remained in the sacrificial order. But isn't Christianity, then, a contradiction in terms? Is a Christian society possible? Aren't Christians always protesters of order and of Satan? Aren't they, consequently, outsiders?

René Girard: Yes. They recreated the sacrificial order. This is historically inevitable and, I would even say, necessary. A change-over that was too abrupt would have been impossible and unthinkable. We have had two thousand years of history and this is essential. My work is related to theology, but it is also related to modern science to the extent that it historicizes everything. It shows that religion must be historicized: it turns men into beings who remain violent but who become subtler, less spectacular, more distant with regard to the animal and sacrificial forms such as human sacrifice. Historic Christianity may well be a historical necessity. After two thousand years of historical Christianity, it seems we have today reached a pivotal period that is either a direct opening onto the Apocalypse, or that prepares us for a period of greater understanding and a subtler treason of Christianity. We cannot close history, nor do we have the right.

Certitudes: The Apocalypse, in your own words, it is the end of history...

René Girard: Yes, according to me the Apocalypse is the end of history. My view is as traditional as possible. The Apocalypse is the advent of the kingdom of God. But one can think there are "small or half-Apocalypses" or crises, that is, intermediary periods...

Certitudes: And you do not believe in Philippe Muray's concept of post-history?

\footnotetext{
4 Philippe Muray (1945-2006) was a French intellectual and novelist. Muray wrote two papers on René Girard's mimetic theory. See Philippe Muray, Ultima Necat I, «La resurrection René Girard » (Paris: Les Belles Lettres, 2015), 12-16 \& Philippe Muray, Essais, « René Girard et la nouvelle comédie des méprises » (Paris : Les Belles Lettres, 2012), 1175-1182. He also interviewed René Girard two times, in 1978 and 1982. See René Girard: Les grands entretiens d'artpress, ed. Benoit Chantre (Paris: Artpress, 2015), 13-46. In 1983, Girard invited Muray to teach French literature for a few months at Stanford University. According to Muray, the Western world is entering a post-historical stage where the abolition of differences (between man and animal, public and private, masculine and feminine etc.) is
} 
René Girard: I appreciate him greatly. But I am certainly a more classic Christian despite my historicism. Apocalyptic texts must be taken very seriously. We do not know if we are living the end of the world, but we have reached a pivotal period. I think that every great Christian experience of such turning points is necessarily apocalyptic to the extent that it encounters men's incomprehension and owing to the fact that this incomprehension is, in a certain way, always fatal. I say it is always fatal but, at the same time, it is never fatal because God always takes things in hand and forgives.

Certitudes: How do you envisage globalization from the perspective of your system? Couldn't globalization be the repetition of the Apocalypse or of post-history? Isn't globalization firstly Babel since we go back to the beginning of Genesis, then on to the Apocalypse as a result of the disappearance of nations?

René Girard: Yes, antagonistic forces transcending every tribal or national distinction are the only things that remain...

Certitudes: In a kind of globalization of order with no possibility of recourse to sacrificial safeguards...

René Girard: The apocalyptic principle defines what you have just said. As soon as there is no possible recourse, or even when there are fewer recourses, anyone who lives Christianity in an intense way feels this. Therefore, even if he is mistaken, he always reckons the end is near and his experience becomes apocalyptic.

Certitudes: At the same time, we are living in an unprecedented historical situation where on the one hand the sacrificial safeguards have fallen and on the other all barriers against mimetic rivalry have been removed...

René Girard: I fully agree with you. I remember a newspaper in which there were two juxtaposed papers. One mocked the idea of the Apocalypse in a certain way; the other was as apocalyptic as possible. There was something fascinating in the contact between these two texts which stood at once face to face while pretending to have nothing to do with each other.

Certitudes: In your essay The One by Whom Scandal Comes, you envision a non-sacrificial society that could well be the most violent possible, a kind of egalitarianism that produces rather than feeds conflict.

continually celebrated in festivals and other entertainments. Muray calls "Homo Festivus" the happy inhabitant of this post-historical stage. The concept of post-history differs markedly from Francis Fukuyama's concept of the "end of history". Although Muray defined post-history in many different ways, he frequently stated its surest sign was men's loss of fear, their readiness to step outside human history - a history which normally implied the acceptance of contradictions, conflicts and negativity. See Philippe Muray, Le Portatif (Paris : Mille et Une Nuits, 2006), 42-43 \& Philippe Muray, Festivus Festivus (Paris : Flammarion, 2008). 
René Girard: The time of the great world fairs, such as the Great Exhibition of London (the famous one to which Dostoyevsky refers) and the Paris Exhibitions, is not that far away from us... The closer we come to true globalization the more we realize that it is not in any way peace among men, that it can be the most extravagant mimetic rivalry. During the time of the great world fairs, we still had this idea that we were living in the same world: we were no longer separated by what separated men before, thus it was necessarily paradise. This is what the French Revolution sought. After the evening of the $4^{\text {th }}$ of August, no more problems! [laughing].

Certitudes: This is true on the global level as well as on the internal level of societies since, for both, egalitarianism masks the necessary differences.

René Girard: America knows this well. It is obvious that class non-difference does not exhaust rivalries but exacerbates them with all that is good and lethal in this phenomenon.

Certitudes: We take note of a new factor: the confrontation of our society with a religion that, for its part, feels no repulsion to violence. This religion is Islam. You devoted an indepth reflection on the Vedas ${ }^{5}$ to evidence the universal spirit of your thought but, ultimately, the status of Islam remains marginal...

René Girard: These are entirely accidental circumstances. I tried to read some translations of the Quran, but they are rather wearisome. André Chouraqui's translation and presentation of the Quran all but put me to sleep! [laughing]. Without any familiarity with the Arabic language, the task is difficult. There are two important translations of the Quran: Denise Masson's and an older translation from Edouard Montet recently reedited by Payot. The differences between the two translations are huge and there is no way to arbitrate between them.

Certitudes: The translations of different surahs in Anne-Marie Delcambre's book L'islam des interdits, clearly show how violence is legitimated in Islam principally through the confrontation with "Infidels". There is a challenge here we do not see how the West can answer... But one can imagine a reformation of Islam, an idea supported by thinkers such as René Guénon and today by many Muslims such as Dalil Boubakeur...

René Girard: Can the West still respond to this challenge on a spiritual level? Regarding what is happening today, there is an interpretation according to which we are witnessing the avatars of Islam's modernization. This theory might be true, but when will this reformation take place? How many years will we have to wait?

Certitudes: The problem is this [modernized] Islam would likely break away from its ideological sources. Yet, it seems difficult to transpose the Quran into a different perspective.

\footnotetext{
${ }^{5}$ René Girard, Sacrifice, tr. Matthew Pattillo \& David Dawson (East Lansing: Michigan State University Press, 2011). The French text was initially published by the Bibliothèque Nationale de France in 2003.
} 
René Girard: Interpretation is where all the difficulty lies. The question of vocalization is essential here. Arabic is a consonantal language like Hebrew and when we vocalize it in Aramaic, we find different translations. I do not know how specialists react to that. But there is something interesting in the fact that, all of a sudden, historical criticism becomes a kind of weapon. It attacked Christianity. The possibility therefore exists of making good use of historical criticism.

Certitudes: Could you expand on the deep reasons that led you, after having denied any Christian meaning to the word "sacrifice", to claim in your last book that you cannot do without it? It is therefore important to preserve the word "sacrifice" in Christian linguistic usage while remaining fully aware that it's the opposite of archaic sacrifice.

René Girard: There is a story behind this. It was a Swiss theologian, Father Schwager, who led me to accept the word sacrifice in its Christian sense. I helped him with the idea of mimetic rivalry, but the Christian usage of the notion and the idea of a founding violence came to our minds at the same time. His book was published at the same moment as mine. Thus, in certain respects, he should be considered the founder of the theory in the same way I am. He tried for several years to convince the German theologians. German theologians are fundamentally divided into two groups: the former Protestant, and the latter more Bavarian and Catholic. He managed to interest them in the theory and I attended their meeting this summer. It is the first time this group of theologians has invited me to speak about my theories. But they are no longer what they used to be.

Certitudes: You mean that they no longer have the same working capacity?

René Girard: German theologians dominated reflection in this area. And now American theologians dominate. They have big personalities but there are also some "practical jokers" among them, some of whom furnish the researches of Prieur and Mordillat ${ }^{6}$. In Things Hidden Since the Foundation of the World, I tried to create a non-sacrificial zone. But my thought now is that there are two types of sacrifice. If one relies, for instance, on the Judgement of Solomon, one distinguishes self-sacrifice from the sacrifice of the other. To seek to speak without mentioning sacrifice is to seek a purely scientific place, a place foreign to any form of sacrifice. There is, accordingly, scientific objectivity in the traditional sense. To deny this objectivity is to say: "no, not at all. We are always in one religious context or another: we must sacrifice ourselves." It is Father Schwager, moreover, who articulates the thesis that a personal conversion is needed in order to understand mimetic desire. A conversion which is not necessarily Christian... All the same, you must come to see yourself as guilty of mimetic desire. And this, I believe, is essential.

${ }^{6}$ Jerôme Prieur and Gérard Mordillat directed the documentary television series Corpus Christi which was released on the Franco-German TV network Arte in 1997. The series sought to examine the Gospel according to John, using a realistic and pluri-disciplinary perspective. Following the success of their television series, Prieur and Mordillat published several books that emphasized contradictions and inconsistencies in the Gospels with respect to Jesus's life. They also questioned the historical origins of the Church. Prieur and Mordillat's approach ignited a number of controversies among historians and theologians in France. 
Certitudes: You mean that sacrifice is conversion, whatever its nature, Christian or otherwise...

René Girard: The passage from the sacrifice of the other to self-sacrifice is conversion. In the Gospels, the proof is the extremely close if rarely perceived relationship between the first Christian conversion-Peter's reconversion after his denial-and Paul's conversion which is marked by Jesus' words: “[Saul, Saul,] why are you persecuting me?" [Acts 9:4 NJB]. Whoever we persecute, it is always Jesus that we persecute. The idea of a nonsacrificial place where one might settle to write a science of religion on which sacrifice had no bearing is a rationalist utopia. In other words, only Christian religion has a truly scientific approach to non-Christian religion.

Certitudes: In defending Christian sacrifice, you defend the religious dimension of Christianity against the idea of a Christianity that would be pure faith, a Christianity without religion?

René Girard: Yes, against a Christianity without religion, this irreligious Christianity we see clearly emerging in the attacks against Mel Gibson ${ }^{7}$ which are in fact attacks against the Passion itself. Journalists were there at the movie theater exits after the premiere screenings in New York. And some spectators said: "But we changed all this, the Passion no longer has the same importance it had before..." It was a prodigious revelation about a certain trend of thought in Christianity today. It seems to me the debate on Mel Gibson's movie-if we put aside its merits or demerits - was a debate on the importance of the Passion, on the pivotal or non-pivotal nature of the Passion.

Certitudes: At the same time, the movie clearly showed (by way of reproaches that it was too violent) just how right you are to say the denunciation of violence in Christ's discourse has not been understood. From the moment you began writing Things Hidden Since the Foundation of the $W$ orld, were you not bothered by the fear of appearing an apologist for the Christian religion?

René Girard: The people who reproach Gibson's use of violence are those who usually do not worry about violence in the cinema or who turn this violence into something good: a victory for freedom, for modernity. Things Hidden Since the Foundation of the World consents, at least a little, to appear an apologia of the Christian religion. The book is looking for this sacrificial place of which I was unaware at the time. This is what Father Schwager showed me. There are gross mistakes such as the attack against the Epistle to the Hebrews which is

\footnotetext{
${ }^{7}$ It is worth mentioning that while René Girard expressed some reservations with respect to Mel Gibson's movie The Passion of the Christ (2004), he nonetheless praised Gibson's cinematographic project. In 2004, Girard expressed his views on Gibson's movie in the French newspaper Le Figaro. The article has been translated into English by Robert Doran and is available online: René Girard, "Mel Gibson's The Passion of the Christ", Antbropoetics X 1 (2004), http://anthropoetics.ucla.edu/ap1001/rggibson/ (accessed November 10, 2017).
} 
ridiculous. There are elements of the Passion in this epistle which now seem absolutely essential to me. For instance, the usage made of Psalm 40: "Sacrifice and offering you have not desired [but a body you have prepared for me; in whole burnt offerings and sacrifices for sin you have taken no pleasure]. Then I said, 'Behold, I have come [ (in the scroll of the book it is written of Me) to do your will, O God]." [Psalm 40:6-8 NSAB]. What does this "Then" mean? It means: since "Sacrifice and offering you have not desired", there is no more sacrifice. Men are, accordingly, exposed to violence, leaving them only two choices: we either prefer to endure violence, or we seek to inflict it on others. Among other things, Christ wants to tell us: it is better to endure violence (this is self-sacrifice) than to inflict it on others. If God refuses sacrifice, he obviously asks of us the non-violence that will prevent the Apocalypse.

Certitudes: Then, Christ asks of us an internal sacrifice...

René Girard: Yes, an internal sacrifice or a self-sacrifice: "I delight to do Your will, O my God." [Psalm 40:8 KJV]. We must recall the good prostitute in the Judgement of Solomon, a text I just mentioned if all too briefly: she prefers to let the child go and is therefore the true mother.

Certitudes: You go so far as to defend an Augustinian Christianity, finally ... The love of giving against the love of passion...

René Girard: Augustine really sees Christianity and Christ's death as essential to every culture. In a certain way, he links Cain and Abel and all murders to the Passion. He sees there is a connection. At the end of The City of God, there are extraordinary texts on this theme which nonetheless appear incomplete to me. We have, at the same time, a very powerful Christian thinker and a man who looks at ancient civilization in what is today a most unusual manner.

Certitudes: In your conversations with Michel Treguer in When These Things Begin, you go as far as to state: "Three quarters of what I say is in Saint Augustine."

René Girard: This was a witticism of mine, but one I believe in a certain way. One discovers in his work extraordinary elements for the definition of mimetic desire. There is a passage in the Confessions-which I cite in Evolution and Conversion-about the two infants who are already rivals, because they compete for the nurse's breast ${ }^{9}$. This is a bit mythical: these two infants are incapable of understanding that the nurse's breastmilk can dry up. But it is a formidable image of the desire of all humanity and of the fact that rivalry is there from the origin. This is what experimental science is discovering today: it discovers there is

\footnotetext{
${ }^{8}$ René Girard, When These Things Begin: Conversations with Michel Treguer (East Lansing: Michigan State University Press, 2014), 133.

9 "I have personally watched and studied a jealous baby. He could not speak and, pale with jealousy and bitterness, glared at his brother sharing his mother's milk. Who is unaware of this fact of experience?" Saint Augustine, Confessions, trans. Henry Chadwick (Oxford: Oxford University Press, 1991), 9. For Girard's comments see Evolution and Conversion, 61.
} 
imitation from the beginning of humanity, in its very life and organization. Imitation is fundamental to the first reflexive movements of the human being.

Certitudes: As soon as you put violence at the heart of man, you are no longer in a Hellenic and irenic universe...

René Girard: It can be said this irenic universe only partially appears in Plato. He has a concern, an anxiety with respect to the mimetic. Derrida very rightly says that one cannot systematize the mimetic in Plato's work. There are insoluble contradictions in it. Plato has concerns about the mimetic, about the fact that men must avoid it like the plague. This is fascinating and absolutely incomprehensible. But if you take a look at primitive prohibitions, you can see the mimetic prohibitions are there. I believe Plato is still in contact with these elements of the past that appear in the Pre-Socratic philosophers but no longer in Aristotle. Aristotle imitates Plato and, meanwhile, the world completely changes on a cultural level: the Alexandrian is what is modern with respect to the universe of Athenian democracy.

Certitudes: Beyond the violence of human relations and mimetic rivalry, is there not a natural desire in man to live in society peacefully, as a homebody? Does this seem a contradiction of your theory?

René Girard: Absolutely not. Mimetic theory doesn't aim to be a philosophy treating the entirety of human life. It simply states there is always enough mimetic rivalry in a society to agitate everything, propelling us towards a sacrifice. But this doesn't mean that everybody is guilty to the same degree. In our society, people are very skilled at avoiding mimetic rivalry, not just instinctively but also deliberately: there is quite an art to avoiding mimetic rivalry which is, in the end, the art of living together. And this is absolutely indispensable.

Certitudes: In your last book, Les Origines de la culture [Evolution and Conversion], you insist a good deal on Darwinism and willingly introduce a Darwinian epigraph for each chapter. You seem to draw from Darwinism the idea of man's inevitable progress...

René Girard: It is Pierpaolo Antonello who introduced the epigraphs. Personally, I wanted to remove them. As for the question of progress, it is not necessarily inevitable because men themselves contribute to it. I acknowledge that there can be a regression. One can think that Islam is supported by the Quran but in the case of "frenzied" Islamists it is quite obvious that the Quran, with the possible exception of the famous sect of the Assassins, has scarcely ever been interpreted in this way. Yes, there may be a regression.

Certitudes: What is so striking, notably in When These Things Begin, is your fundamental optimism, your idea that there will always be a way to what is best, notwithstanding the atmosphere of Augustinian pessimism. It is, no doubt, mimetic rivalry that may have mislead Augustine in his polemics...

René Girard: But this optimism can also be seen in Augustine... Henri-Irénée Marrou said that we should give up choosing the most polemical moment in Augustine to define him in 
his entirety. And if we take a look at the texts on grace, which do not belong to his quarrel with Pelagius, we can put together a far more balanced Augustine. Mimetic rivalry is something without which it would be very difficult to write: it supports the writer in his efforts. [laughing]

Certitudes: Christianity keeps permeating modern society despite the latter's reluctance. Your position, finally, is close to that of Chesterton who spoke of "the modern world...full of the old Christian virtues gone mad." You say the Christian message of victimhood permeates contemporary life and, at the same time, one has the impression of a complete loss of any awareness of violence. It is very paradoxical.

René Girard: I believe there is a twofold movement. We must not forget that there is also a society of fear. Many people think violence in our world is increasing. There is an overlap between the two movements. In the first half of the $20^{\text {th }}$ Century, Catholicism in France and English "para-Catholicism" gave birth to a multitude of talented people, especially during the interwar period. This is no longer the case today. I know you do not go easy on Jacques Maritain. There are some platitudes in his work, but some absolutely admirable things as well. Books such as The Dream of Descartes and Les Trois Réformateurs are written in a polemical vein which later disappears because he became nearly too official a figure.

Certitudes: One notes a contemporary phenomenon of unawareness with respect to violence. Our contemporaries are certainly afraid of violence, but they are aware of it as of an external force, especially in the case of terrorism. It seems they have completely lost sight of the Christian message teaching us that violence is situated at the heart of man. It is a violence that threatens us but that we cannot expel from ourselves.

René Girard: Yes, we always feel ourselves the victims of a violence coming from without. Mimesis should be studied at the more fundamental level which is that of reciprocity between men. Between animals, there is no reciprocity: even when they fight, they do not look each other in the eyes. In the first story of The Jungle Book, animals cannot look Mowgli, the wolf-child, in the eye. The animal sees nothing in his eyes that might hold its attention. This is not in any way the triumph of man over animal, despite how Kipling introduces it in accordance with $19^{\text {th }}$ Century views on triumphant humanism. In this book, all the stories end with collective murders, behind which are hidden rather ancient Indian myths. What makes me curious is the reciprocity that remains in man. If you have a good relationship with someone, you are in a context of reciprocity, but violence can arise very quickly between the two of you. If I hold my hand out to you and you don't shake it then there is no reciprocity and the hand that I offered will immediately retreat. That is to say, it will imitate the violence of the other. The relation of violence is a relation of reciprocity as is the "give and take" relation. But the relation of reciprocity is very difficult to change in the sense of reverting [from good] to bad reciprocity. On the other hand, nothing is easier than to move from good to bad reciprocity. As soon as men stop treating each other in a decent way, they get the impression that violence comes from the other. From their point of view, they are merely returning the favor, which amounts saying to the other: I understood what 
you meant and so respond in a similar fashion. And to be certain that the other will understand, one outbids the other. The other, consequently, interprets this as an act of aggression. We can clearly show that at the most basic level there is always incomprehension, the incomprehension of one by the other. The escalation can increase without anyone becoming aware of the way he is himself contributing to it.

Certitudes: Nevertheless, we lived for fifty years in the context of a nuclear strategy that rightly foresaw an escalation of violence...

René Girard: Certainly. But in this specific case there were extraordinary acts of caution because Khrushchev decided to withdraw the nuclear missiles from Cuba. There is something crucial in this act. It was the only moment that terrified the statesmen themselves. Today we know that some countries are trying by all means to get these weapons and that they are determined to use them. We have thus passed another threshold.

Certitudes: This perversion of Christian ideas is also exemplified in the concept of the "victim". In our society, victims are everywhere and victim one-upmanship becomes a means of assaulting the other. One uses what he knows of the other person to claim: "I am your victim therefore you are a persecutor."

René Girard: Yes, but we must recognize that there is a legitimate use behind the abusive uses of the modern concern for victims. We are the only society that takes a detached interest in victims. And that is an extraordinary superiority.

Certitudes: You clearly developed this idea in When These Things Begin: victimization as a weapon, as a form of violence...

René Girard: I believe the crucial moment in the West is the invention of the hospital. Primitive societies take care of their own dead. What is characteristic of the hospital is the fact of taking care of everybody. As the Hôtel-Dieu [Hostel of God] it is, therefore, charity. And it is obviously an invention of the Middle-Ages. All good things in our society may be subject to abusive uses. When Voltaire wrote Candide, he was looking for a counterexample, a society superior to the West, but he did not find it. It's the reason he turns [instead] to Eldorado, a place that doesn't actually exist. He had himself written poems such as Le Mondain [The Worldling)] — "O what a fine time, this century of iron!"” [“O le bon temps que ce siècle de fer!']. His main idea was that modern society was the best of all. He aimed to annoy the ladies of his Salon who spoke of Leibniz instead of him as they ought to have done... [laughing]. Voltaire has an extraordinary awareness of mimetic rivalry. In Candide, there is this character, Signor Pococurante, who owns everything. This Venetian noble receives Candide and his servant Martin as guests and despises his own wealth. He has numerous art paintings but no longer looks at them. Furthermore, he states that only fools admire everything in the work of a great artist; for his part he likes only what is useful to him. After they bid farewell to the Venetian, Candide says to his servant Martin: "this man is the happiest of all mortals, for he is above everything he possesses." The Venetian wants to appear superior to all his possessions, but in so doing he cultivates a form of desire. 
Certitudes: There is a final subject you discuss, namely, that of truth, of verification. Behind the subject of truth is the idea of the figural: everything is a figure of the truth. In $L a$ Voix Méconnue du Réel10 [The Unknown Voice of the Real], you propose the idea of a truth we cannot escape- the truth of mimetic theory - that somehow goes beyond the evidence for or against it...

René Girard: The real issue is that of scientific truth. The argument leveled against my theory is always Karl Popper's falsifiability. People tell me that my theory is not falsifiable. No more so than the theory of evolution, I reply. Besides, there are all sorts of things of which we are certain. I take this direction now. It is what we call in English "common knowledge". Today, one need not explain that witches are not guilty, despite the $15^{\text {th }}$ Century witch hunts. It is "common knowledge" to the extent that no one will refute you because it's obvious. The question is whether this "common knowledge" belongs to science. My answer is: yes, but it is a science so certain it does not need to demonstrate its truth, a science with too many possible verifications for it to be necessary to go through the whole list.

Certitudes: Our Journal is entitled Certitudes [Certainties]. It is a reference to the Italian thinker Giambattista Vico, who developed the theory of the "certum". Certum is not "verum". In a certain way, Vico is an anthropologist who is passionate about Latinity in all its historical manifestations. Your eloquence reminds us of Vico. Vico's purpose is not philosophical. His theory of "New Science" stands opposed to the science of Descartes, and is new as such. Descartes aimed to reach the "verum", that is, an objective science. And you state: "We are always included in the fundamental science that we develop; it is not, therefore, an objective truth but a total truth that envelops us..."

René Girard: The idea that we can reach the "certum" from texts is constantly belied by the existence of the judicial system, the system of evidence. The question is that of knowing at what point we really enter the domain of the "certum". In anthropology, there is no immediate verification, since everything is a matter of indirect evidence. Everything is linked to the proliferation of clues and so entails a scientific attitude. The work of the ethnologist requires this proliferation of indirect clues.

${ }^{10}$ René Girard, La Voix Méconnue du Réel (Paris : Grasset, 2002). This is the title of a collection of essays written in English by René Girard and translated into French by Bee Formentelli. The original English versions collected in this volume can be found in René Girard, To Double Business Bound (Baltimore: John Hopkins University Press, 1978), Mimesis and Theory: Essays in Literature and Criticism (Stanford, CA: Stanford University Press, 2008) and The Girard Reader, ed. James G. Williams (New York: Crossroad Herder, 1996). It is Bee Formentelli who proposed the title La Voix Méconnue du Réel (The Unknown Voice of the Real - a reference to the violence of the crowd and the innocence of its victims, something ancient myths serve to conceal). Girard was more than a little pleased with this title. In his French foreword, he states: "It is the unknown voice of the real that I have tried all my life to heed and to translate. These words capture so well what I aimed to do they made me ask myself whether I had really done it." [C'est bien la voix méconnue du réel que, toute ma vie, je me suis efforcé d'écouter et de transcrire. Ces mots disent si bien ce que j'ai voulu faire qu'ils m'obligent à me demander si je l'ai vraiment fait.]. 
Certitudes: You dared to entitle one of your books: La Voix Méconnue du Réel [The Unknown Voice of the Real. How has this text on truth and reality been received?

René Girard: La Voix Méconnue du Réel is the title chosen by the translator. I think the translation is very good, but some dispute it. That's the problem of translation from English to French. It is on the word "réel" that the translation is disputed. The translation becomes impossible because of similarities between the two languages. It is the linguistic issue of "false friends". Seemingly perfect translations make no sense while the translated words remain perfectly comprehensible in the language from which they are translated.

Certitudes: Did teaching and publishing in the United States give you more freedom to think and research than you would have had if you'd stayed in France? Was the antireligious prejudice less strong in the United States?

René Girard: The United States is my only anthropological experience! [laughing]. No, the prejudice against religion is exactly the same. But the statistical figures are different. For instance, the "modernized" church succeeded in "decatholicizing" many people. Catholics account for seventeen-millions persons in the United States. I arrived in the country prior to the Council and, at that time, they made up $75 \%$ of regular churchgoers. This figure represented far more than Europe in its entirety. Today, American Catholics make up $30 \%$ of churchgoers, which is still far superior to Europe. Fundamentalists are not the madmen portrayed by French media. To call them "fundamentalists" is, moreover, excessive. They are committed to the education of their children. They mistrust the "sex education" classes held in certain schools, which is perfectly legitimate. Admittedly, nationalists get their votes, but in a way all the political parties bear some responsibility. Protestant churches are, by the way, in a worse state of decomposition than the Catholic Church.

Certitudes: What is the current situation of Protestant churches, of Baptists for example?

René Girard: This issue is quite complex. Baptists have always been a bit fundamentalist. There are many practitioners in this branch of Protestantism. There are what we call the "great denominations" which include the Episcopalians (Anglicans in the international version), the Presbyterians of Scottish origin, the Methodists, as well as the Quakers. Many of these often very rigorous churches, especially the Presbyterians, have undergone an evolution, the result of which has been a slackening of faith. Hence, to speak about God today in these churches can seem a little bit impolite...! [laughing]. They have become humanitarian clubs of a kind.

Certitudes: You state with an extraordinary force that religion is the mother of everything...

René Girard: I do think so. The strength of American Catholicism is the Protestants who convert to Catholicism. If you tell them Catholicism is in a state of decomposition as well, they reply: "Yes, but Catholicism is the only church that has a chance to live and survive." 
Certitudes: They must be all the more distressed about the fading of Catholicism... What was, for instance, the reaction of the Catholic hierarchy to Mel Gibson's The Passion of the Christ?

René Girard: Many Protestants stated on several television channels: "this movie shows to what extent we have suppressed all forms of religious imagery". Hence, there were sometimes very good reactions from Protestants. As for the Catholic hierarchy, a declaration of the bishops stated: "We do not have an opinion". They maintained that they did not judge Mel Gibson, that his commitment was rather good per se, but that the movie could also be misunderstood as justifying violence, which is really erroneous. The movie does not justify violence. In the United States, we have a Catholic television channel which is called "The Eternal Word Television Network" (EWTN). It is splendid! [laughing]. It is Mother Angelica who directs the channel. People say mass, pray the Rosary several times a day, and the cultural programs are often of a high quality, unlike those endlessly repeated on other media outlets.

Certitudes: In France, the television channel KTO has been up and running for three years. The channel was prepared to defend Mel Gibson's movie, but it has a close relationship with the episcopate which asked it to tone down its analyses...

René Girard: A journalist from KTO once questioned me. I had just come back from the United States and was a bit tired. I realized right away that she wanted me to say something against Mel Gibson's movie. That woke me up! [laughing]. 